\title{
Geotechnical risk management for Victor Mine closure
}

\author{
M Desjardins De Beers, Canada \\ PJH de Graaf Anglo American, De Beers Group of Companies, Australia
}

G Beale Piteau, UK

M Rougier Golder, Canada

\begin{abstract}
The De Beers Canada Victor Diamond Mine is located in the James Bay lowlands of Northern Ontario. This case study presents the evaluation of geotechnical stability and pit lake filling. The work was used to support decisions that informed risk assessments and the closure plan for two key phases:

1. Active closure, with personnel undertaking rehabilitation activities in and surrounding the pit.

2. Post-closure, when personnel and equipment have been demobilised from the mine site.
\end{abstract}

Risk-based monitoring plans were developed along with Trigger Action Response Plans (TARPS) to ensure that closure of the pit proceeds safely and efficiently while satisfying regulatory requirements.

Active mining operations in the open pit ceased in mid-2019 and pit filling is underway. The pit required the installation of a major dewatering system, with up to $94,000 \mathrm{~m}^{3} /$ day, pumped mostly from dewatering wells. Considerations for closure included the site remoteness, safety, global and local stability, water quality of the pit lake, permitting commitments, and closure regulations in the province of Ontario. A major consideration was the rate of pit filling. Rapid pit lake filling using water from the nearby Attawapiskat River leads to more favourable stability and environmental outcomes. A simple hydrogeological model was used to predict the filling rate and the final pit lake level for a number of potential closure options. This was used to schedule a phased geotechnical monitoring approach to ensure the safety of the operators as the pit walls became increasingly pressurised. A trade-off study has informed the preferred approach for pit lake development. Active pit closure has recently been completed and closure reclamation is ongoing.

Keywords: mine closure, slope stability, geotechnical risk, pit lake, TARP, trigger action response plan

\section{Introduction}

This paper describes the planning and steps taken in advance of the closing of the open pit at the Victor Diamond Mine. Physical stability assessments and a pit lake filling model were completed which informed a risk assessment to identify the geotechnical risks associated with closure. Mining at Victor ceased on 5 March 2019. Pit flooding began slightly before (16 February 2019) when the sump pump was removed. Due to the high rate of groundwater inflow, the sequence of shutting down and decommissioning the dewatering wells needed to be carefully planned.

The decommissioning sequence (active closure) required geotechnical monitoring systems to keep operators safe during retreat mining. Once all in-pit operations had been completed, the post-closure phase requires verification monitoring, access control, and regulatory compliance. 


\section{Victor Mine history}

\subsection{Location and climate}

Victor Mine is situated in the James Bay lowlands of Northern Ontario, $90 \mathrm{~km}$ west of the town of Attawapiskat (as shown in Figure 1). It is Ontario's first diamond mine and the second of three in Canada for DeBeers. It is a remote fly-in/fly-out operation that is supported by a winter 'ice' road available for 4-6 weeks to bring supplies and equipment to site. Several kimberlite pipes have been discovered in the area since 1987, however only three pipes were mined at the Victor operation creating a single open pit. First ore was mined in March 2008 and last ore in March 2019, a period of 11 years.

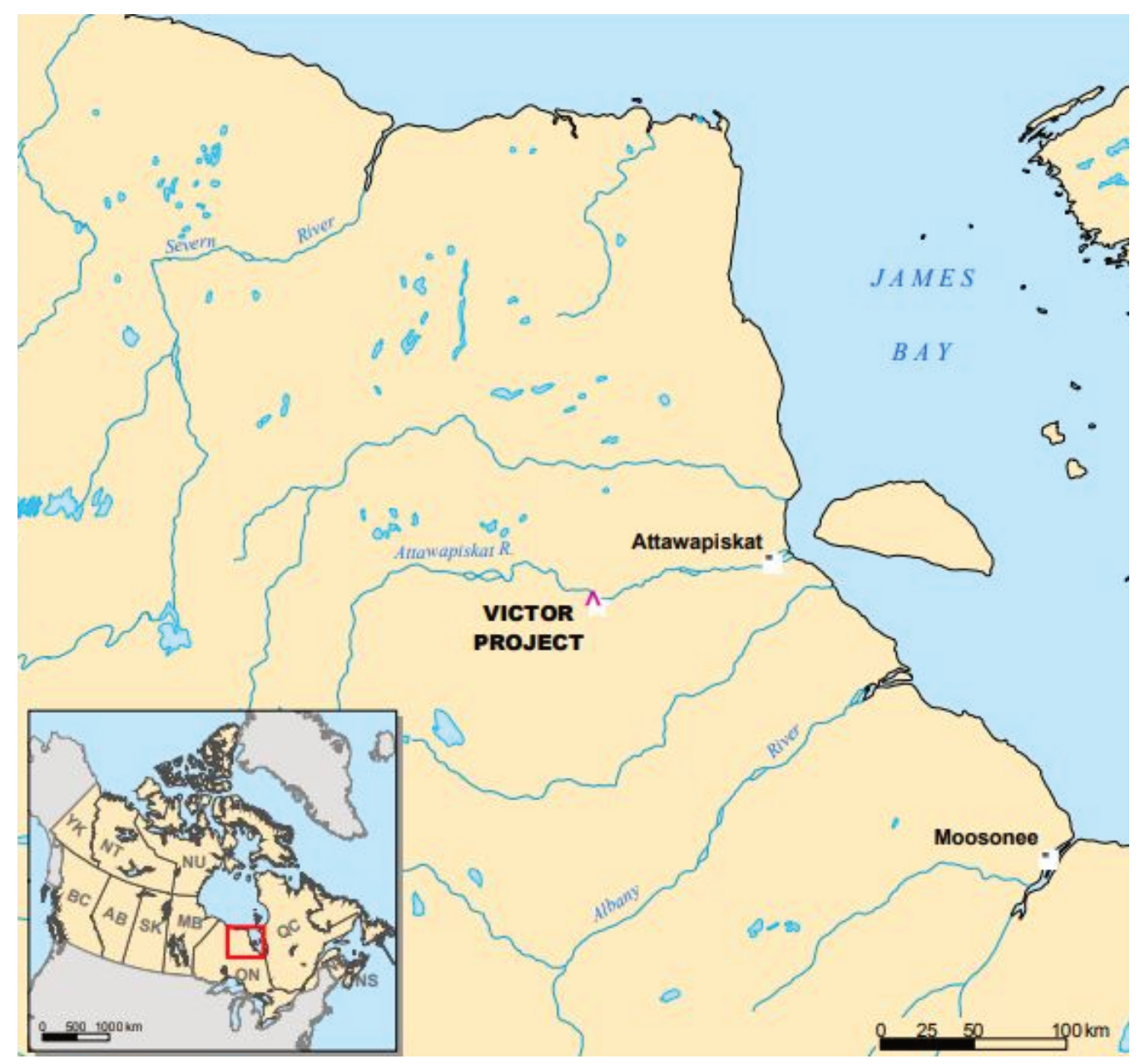

Figure 1 Victor Mine location map

Victor Mine has a subarctic climate and some of the most extreme seasonal temperature variations anywhere in the world; with long cold winters, and short cool to mild summers. Winter temperatures can drop to below $-40^{\circ} \mathrm{C}$. Summer temperatures may exceed $30^{\circ} \mathrm{C}$. The average annual precipitation and evaporation are approximately $690 \mathrm{~mm}$ p.a. and $430 \mathrm{~mm}$ p.a. respectively. The residual precipitation (difference between precipitation and evapo-transpiration) is $260 \mathrm{~mm}$ p.a. The Attawapiskat River lies about $3 \mathrm{~km}$ to the north of the open pit and forms the major surface water drainage of the region. Numerous other rivers and creeks occur close to the mine site.

\subsection{Geological setting}

The stratigraphy model is relatively simple, comprising three kimberlite pipes intruded into flat-lying sedimentary sequence of Silurian limestone (105 m thick) overlying Ordovician mudstones and sandstones (135 $\mathrm{m}$ thick), which unconformably overlie Precambrian granitic basement. The bedrock sequence is in turn 
overlain by $30 \mathrm{~m}$ of lacustrine clay overburden (muskeg). The upper portion of the limestone (about $50 \mathrm{~m}$ ) is weathered and has increased jointing, iron staining, and some enhanced karst development (Rougier et ${ }^{\circ} a l$. 2015). The pipes consist of multiple intrusions and various kimberlite facies and are surrounded by an alteration zone in the limestone. Figure 2 illustrates the pit geology and geotechnical domains.

\begin{tabular}{|c|c|c|c|c|c|c|c|}
\hline \multirow{25}{*}{$\begin{array}{l}\text { Limestone } \\
\text { Contact Zone } \\
\text { Overburden } \\
\text { North West Kimberlite (Grade) } \\
\text { North West Kimberlite (No Grade] } \\
\text { South West Kimberlite (MPK) } \\
\text { South West Kimberlite (OPK) } \\
\text { South West Kimberlite (THK) } \\
\text { VNW (Country Rock Breccia) } \\
\text { vBlip } \\
\text { vNW } \\
\text { Weathered Limestone }\end{array}$} & \multicolumn{7}{|c|}{ Geotechnical Design Parameters } \\
\hline & \begin{tabular}{|c} 
Geotechnical \\
Domain
\end{tabular} & \begin{tabular}{|c|} 
Domain \\
Description
\end{tabular} & $\begin{array}{c}\text { Batter } \\
\text { Angle (") }\end{array}$ & $\begin{array}{l}\text { Bench } \\
\text { Helght } \\
\text { (m) }\end{array}$ & $\begin{array}{l}\text { Bench } \\
\text { Width } \\
\text { (m) }\end{array}$ & $\begin{array}{l}\text { IRA } \\
(0)\end{array}$ & \begin{tabular}{|l|} 
Maximum \\
Stack \\
Height (m) \\
\end{tabular} \\
\hline & 1 & $\begin{array}{l}\text { Overburden } \\
\text { (Clay) }\end{array}$ & - & $10-20$ & - & 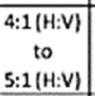 & - \\
\hline & " & $\begin{array}{l}\text { Weathered } \\
\text { Limestone }\end{array}$ & 70 & 10 & 6.5 & 45 & 100 \\
\hline & III & $\begin{array}{c}\text { Country Rock } \\
\text { Breccis }\end{array}$ & 45 & 5 & 5.0 & 27 & 100 \\
\hline & \multirow{6}{*}{ iv } & \multirow{2}{*}{$\begin{array}{l}\text { IV(a) - Contact } \\
\text { Zone - Bllp } \\
\text { Alteration Halo }\end{array}$} & 70 & 10 & 6.5 & 45 & 60 \\
\hline & & & 70 & 15 & 9.5 & 45 & 60 \\
\hline & & \multirow{2}{*}{$\begin{array}{c}\text { IV(b)-Contact } \\
\text { Zone-Other } \\
\text { Limestone/ } \\
\text { Kimberlite } \\
\end{array}$} & 70 & 10 & 6.5 & 45 & 60 \\
\hline & & & 70 & 15 & 9.5 & 45 & 60 \\
\hline & & \multirow{2}{*}{\begin{tabular}{|c|} 
IV(b) - Contact \\
Zone - Below \\
$230 \mathrm{~L}$ \\
\end{tabular}} & 70 & 10 & 4.75 & 50 & \\
\hline & & & 70 & 20 & 9.5 & 50 & \\
\hline & \multirow{10}{*}{ v } & \multirow{2}{*}{$\begin{array}{c}V(0) \text { - Limestone } \\
(260-280)\end{array}$} & 76 & 10 & 6.0 & 50 & 100 \\
\hline & & & 76 & 20 & 7.5 & 58 & 100 \\
\hline & & \multirow{2}{*}{$\begin{array}{c}\mathrm{V}(\mathrm{b}) \text { - Limestone } \\
(340-20)\end{array}$} & 80 & 10 & 6.0 & 52 & 100 \\
\hline & & & 80 & 20 & 7.5 & 61 & 100 \\
\hline & & \multirow{2}{*}{$\begin{array}{c}\mathrm{V}(\mathrm{c}) \text { - Limestone } \\
(70-110)\end{array}$} & 80 & 10 & 6.0 & 52 & 100 \\
\hline & & & 80 & 20 & 7.5 & 61 & 100 \\
\hline & & \multirow{2}{*}{$\begin{array}{c}\mathrm{V}(\mathrm{d}) \text { - Limestone } \\
(150-180)\end{array}$} & 76 & 10 & 6.0 & 50 & 100 \\
\hline & & & 76 & 20 & 7.5 & 58 & 100 \\
\hline & & \multirow{2}{*}{$\begin{array}{l}\text { V- Limestone - } \\
\text { Below } 230 \mathrm{~L}\end{array}$} & 80 & 10 & 4.0 & 60 & \\
\hline & & & 80 & 20 & 5.0 & 67 & \\
\hline & vi & Kimberlite & 80 & 10 & 6.0 & 52 & $\frac{100}{100}$ \\
\hline & VII & Red Head Rapids & 0. & 20 & 7.5 & 63 & \\
\hline & & \begin{tabular}{|c|} 
Mudstone \\
Churchill River \\
\end{tabular} & & & & & \\
\hline & viII & Mudstone & 90 & 10 & 10.0 & 45 & \\
\hline
\end{tabular}

Figure 2 Victor pit simplified geology and slope design sectors

These geologic (country rock and orebody) conditions have resulted in a stable pit with low risk of large-scale failure. Historically, small rockfalls have been common especially during freshet, rain events, or during freeze thaw cycles. Rockfalls tend to originate from areas where less competent rock is observed such as contact zones, blast-damaged crests, in the Red Head Rapids Formation (weaker mudstones and shales), or where more competent blocky layers are undercut.

Initial cuts in the clay overburden performed poorly, resulting is localised slumping. This was resolved in subsequent cutbacks by flattening the slope to 4:1. Slow erosion of sand cells (limestone-fill cavities) and overburden slopes was also common. Figure 3 summarises the most significant falls of ground during the life-of-mine. Based on historical performance, it is not expected that any new failure mechanisms will manifest during closure. As is evident from Figures 3 and 4, Victor Mine has exhibited excellent slope performance. 


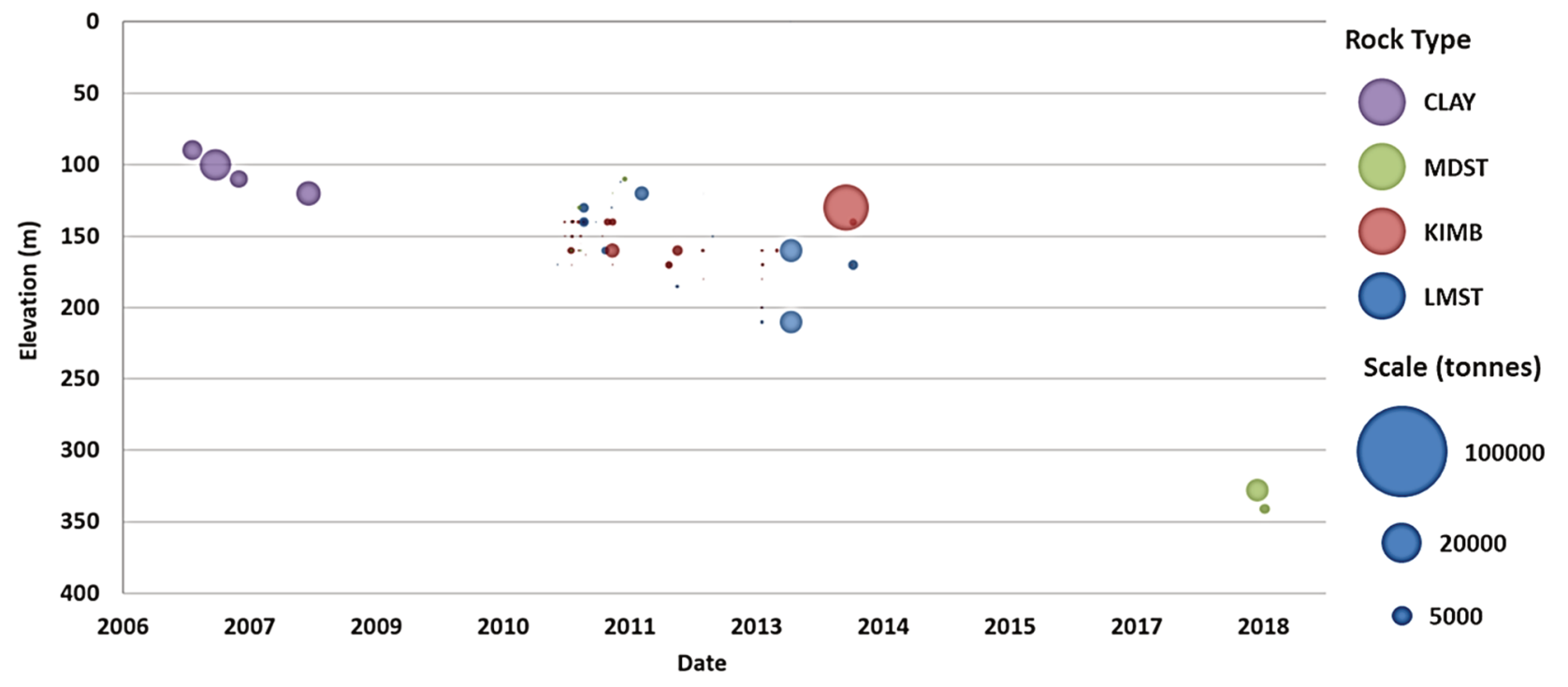

Figure 3 Summary of Victor Mine slope instabilities over life-of-mine

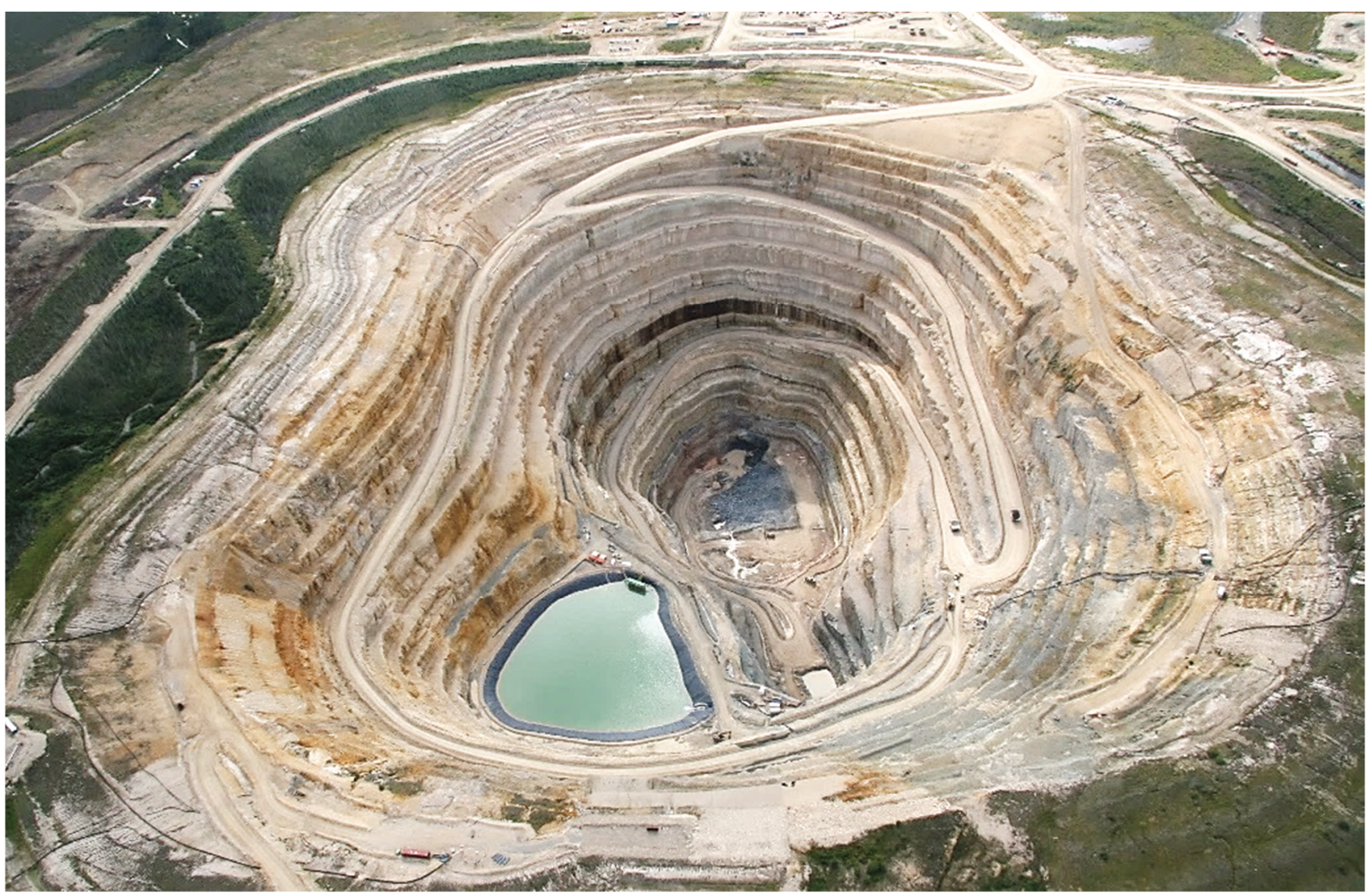

Figure 4 Overview of Victor Mine looking northeast. Note the shallow overburden slopes and excellent limestone slope performance

\subsection{Hydrological setting}

The limestone formations occur to a depth of $220 \mathrm{~m}$ and have high horizontal hydraulic conductivity values. Because the pre-mining groundwater table was at surface, dewatering began in conjunction with mining in early 2007 with the installation of perimeter dewatering wells. By 2008, as more wells were installed, the total dewatering rate had reached $75,000 \mathrm{~m}^{3} /$ day (Figure 5). The maximum dewatering rate of approximately $94,000 \mathrm{~m}^{3} / \mathrm{d}$ was reached in the winter of 2011 (Itasca 2019), after which time the dewatering rate began to slowly decrease over time due to the regional aquifer drawdown. Below the limestone sequence, the 
underlying Red Head Rapids formation includes layers of permeable sands and limestones, with interbedded shales and mudstones.

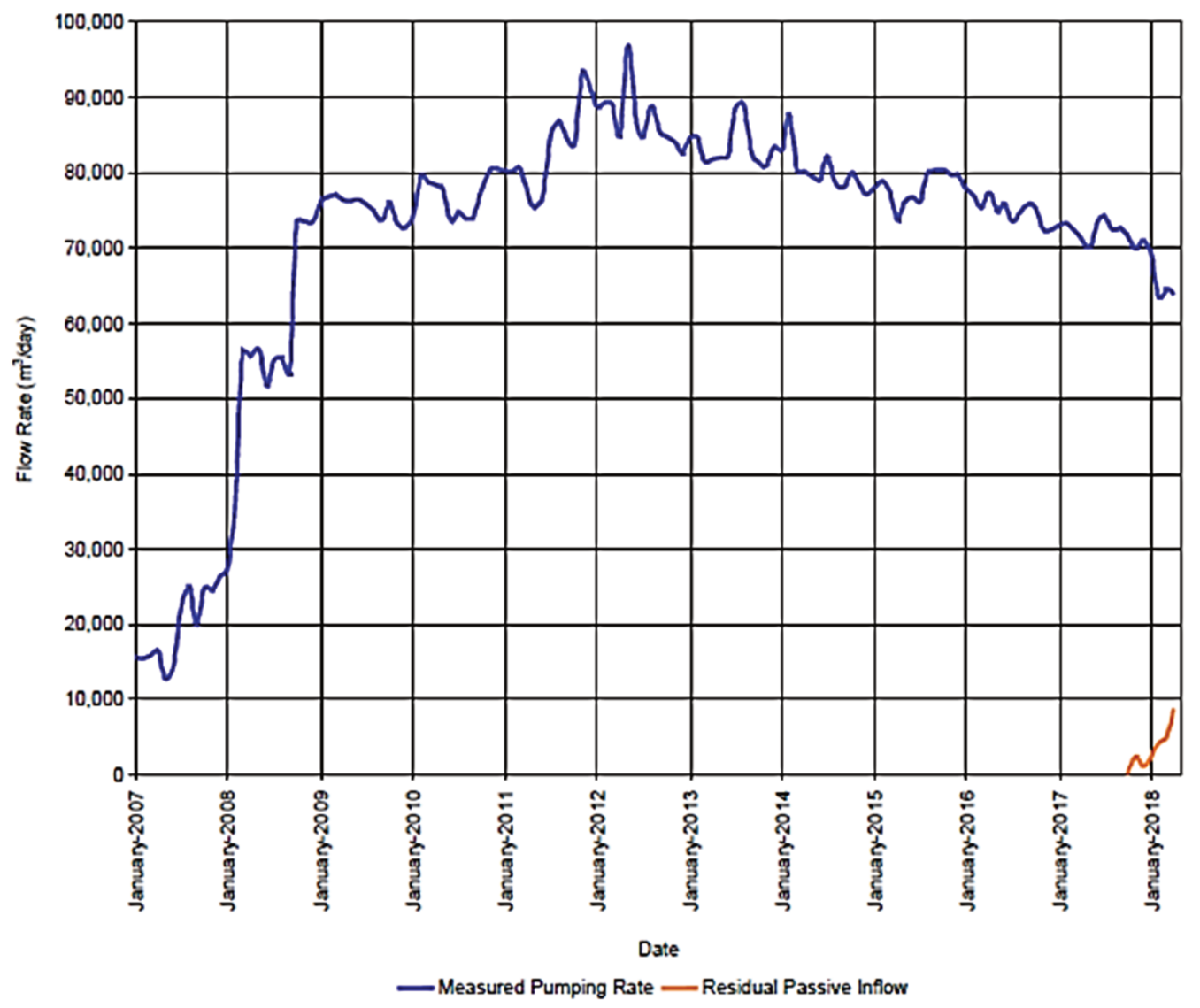

Figure 5 Historical Victor Mine daily pumping rate

\section{Stability assessments}

\subsection{Stability analysis during pit lake filling}

Stability analyses were undertaken to determine the stability of the final pit void and quantify the factor of safety beyond the pit crest, and ultimately to define the required crest setback distance for closure requirements (i.e. closure bund location). These were performed using the RocScience SLIDE software. The highest risk of a pit wall failure is expected to be at the beginning of closure as the dewatering pumps are shut-off and groundwater levels rebound before the pit lake develops. This was confirmed by the results of the five pit filling scenarios analysed. As the pit lake progressively fills, the water acts to equalise pore pressures in the surrounding pit slopes.

The stability analyses included pit lake levels ranging from $0 \%$ to $100 \%$ full in $25 \%$ increments. At $0 \%$ there is no water in the pit, however the lower pit walls are assumed fully saturated to the top of the Red Head Rapids formation. At $100 \%$, the water level is set to the predicted level of the $98.5 \mathrm{~m}$ bench level $(81.5$ masl), which is approximately $2 \mathrm{~m}$ below the surface topographic elevation and is the pre-mining water level (Itasca 2019). Figure 6 shows an example SLIDE model with increasing water levels and the failure path preference through the basal weak mudstone and shale layers described in Section 2.2. 


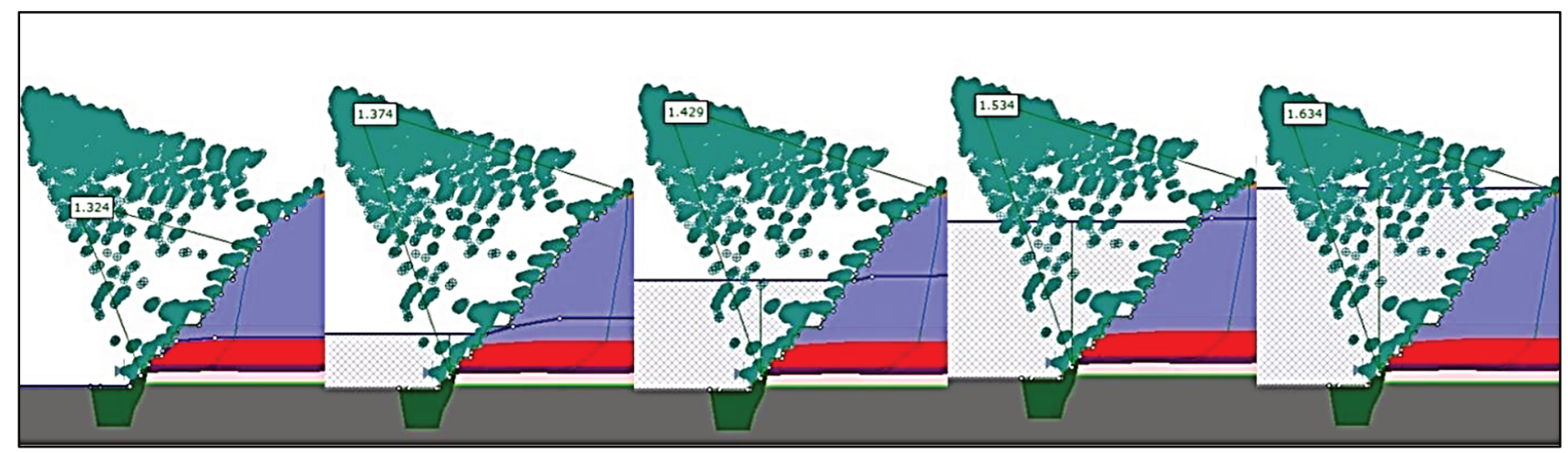

Figure 6 Example of RocScience SLIDE cross-sections showing analysis at increasing pit lake water levels

The stratigraphic sequence of blocky limestone overlying significantly weaker mudstones and shales for the bottom $40 \mathrm{~m}$ of the pit walls presented a new failure mechanism during the final year of the mine life. There was potential for bench scale rock mass and block sliding or ploughing failure. The sub-vertical cross-joints in the limestone acted as release features (back-planes and side-planes or as wedges) for the sliding failure. Previous stability analyses conducted (Rougier \& Smith 2017) demonstrated that they were sensitive to the assumed strength along the bedding and cross-joints and we very sensitive to the assumed slope water conditions. The controlling factors for slope performance were determined to be the weakness of the underlying mudstone shales (Table 1), the uncertainty on the percent rock bridge in the cross-joints, and the water condition considered. Significant dewatering efforts were undertaken during operation to prevent the ploughing failure from occurring.

Table $1 \quad$ Material properties used in SLIDE analysis

\begin{tabular}{|c|c|c|c|c|c|c|c|}
\hline Lithology & $\begin{array}{l}\text { Strength } \\
\text { type }\end{array}$ & $\begin{array}{l}\text { UCS } \\
\text { (MPa) }\end{array}$ & GSI & $m_{i}$ & $\begin{array}{c}\text { Unit } \\
\text { weight } \\
\left(\mathrm{kN} / \mathrm{m}^{3}\right)\end{array}$ & $\begin{array}{l}\text { Poisson's } \\
\text { ratio }\end{array}$ & $\begin{array}{c}\text { Young's } \\
\text { modulus } \\
\text { (GPa) }\end{array}$ \\
\hline Limestone & $\begin{array}{l}\text { Generalised } \\
\text { Hoek-Brown }\end{array}$ & 45 & 65 & 10 & 27 & 0.3 & 24 \\
\hline $\begin{array}{l}\text { Red Head Rapids } \\
\text { (shale) }\end{array}$ & $\begin{array}{l}\text { Generalised } \\
\text { Hoek-Brown }\end{array}$ & 16 & 40 & 10 & 27 & 0.3 & 4 \\
\hline $\begin{array}{l}\text { Churchill River } \\
\text { (mudstone) }\end{array}$ & $\begin{array}{l}\text { Generalised } \\
\text { Hoek-Brown }\end{array}$ & 2 & 100 & 4 & 27 & 0.3 & 0.3 \\
\hline $\begin{array}{l}\text { Basement } \\
\text { Formations }\end{array}$ & $\begin{array}{l}\text { Generalised } \\
\text { Hoek-Brown }\end{array}$ & 75 & 50 & 10 & 27 & 0.3 & 30 \\
\hline
\end{tabular}

UCS - uniaxial compressive strength; GSI - geological strength index.

The results of the pit filling stability analysis show that no large-scale instability is expected, with factors of safety above 1.3 for all stages of filling. As expected, the rising pit lake level improves stability (Figure 7).

Design acceptance criteria (DAC) guidelines for operational slope design (based on scale of instability and consequence of failure) are provided by Read \& Stacey (2009); adjustments for long design service life are typically done using engineering judgement. De Beers operational slope DAC are aligned with the Large Open Pit (LOP) project guidelines and were designed to meet these criteria. For long-term closure, de Graaf et al. (2019) describe how Victor Mine closure specific DAC were developed based on: i) confidence in design inputs, ii) failure consequence, and iii) design service life. This resulted in DAC for closure crest stability of factor of safety (FoS) $>1.6$. 


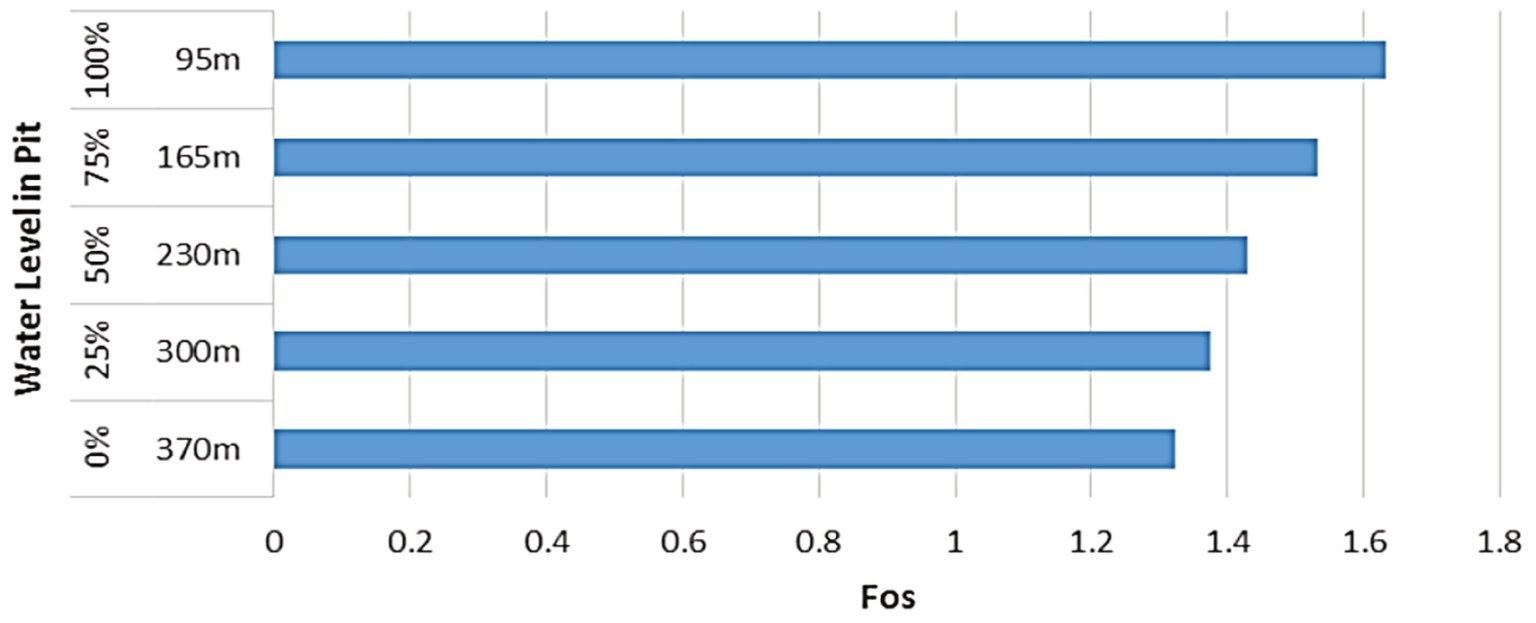

Figure $7 \quad$ Example of increasing factor of safety as pit lake level rises

\subsection{Stability of overburden slopes}

Erosion due to wind or water can affect open pit stability either due to wave generation on the pit lake or by piping caused by pit inflow that has the potential to undercut the overburden slope. Piping erosion through a sand layer was evaluated (See 'Sand Cell' locations in Figure 8), and a worst case scenario was considered where the undercut slope could potentially slump, pushing the crest up to $15 \mathrm{~m}$ back. As the equilibrium water level will be above any near-vertical rock faces, any failure due to piping mechanism would not likely cause a large-scale retrogression of the pit rim. Equally, the existing 4:1 overburden slopes are considered too shallow to promote significant crest slumping.

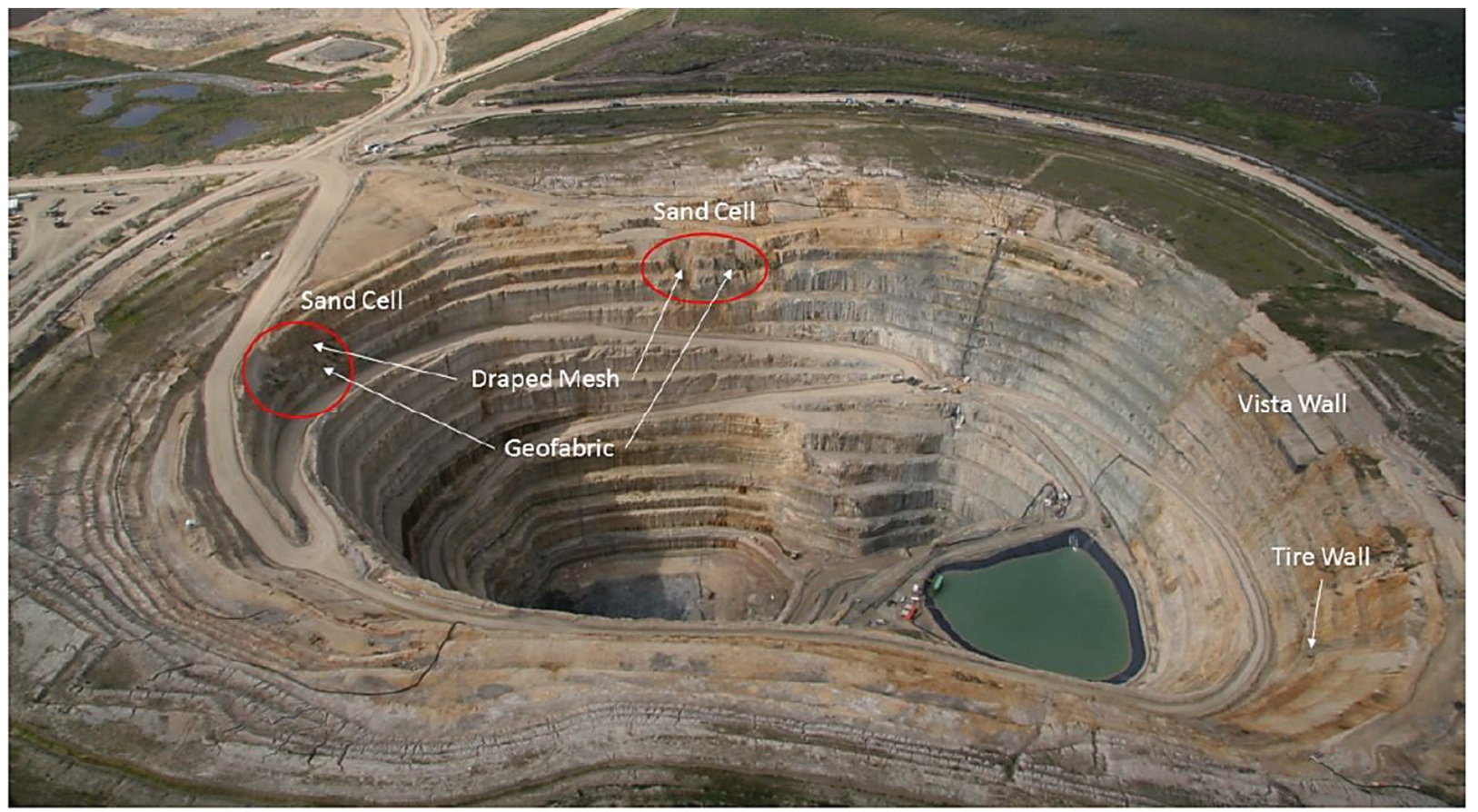

Figure 8 'Sand Cell' locations within Victor Pit including engineered support structures

Erosion of the shoreline due to wind and wave action once the water-level reaches equilibrium was considered a possible mode of failure. The predicted final steady-state water-level elevation is close to the pit crest (Figure 9). At this level, the slopes are gentle to very-gentle (between $1-5^{\circ}$ ), increasing to a moderate slope angle of $14^{\circ}$ underwater. At these low angles (Figure 10), it is postulated that sediment erosion will be at equilibrium with deposition. Further, any material movements at these grades would not be expected to be progressive in nature due to limited mobility. 


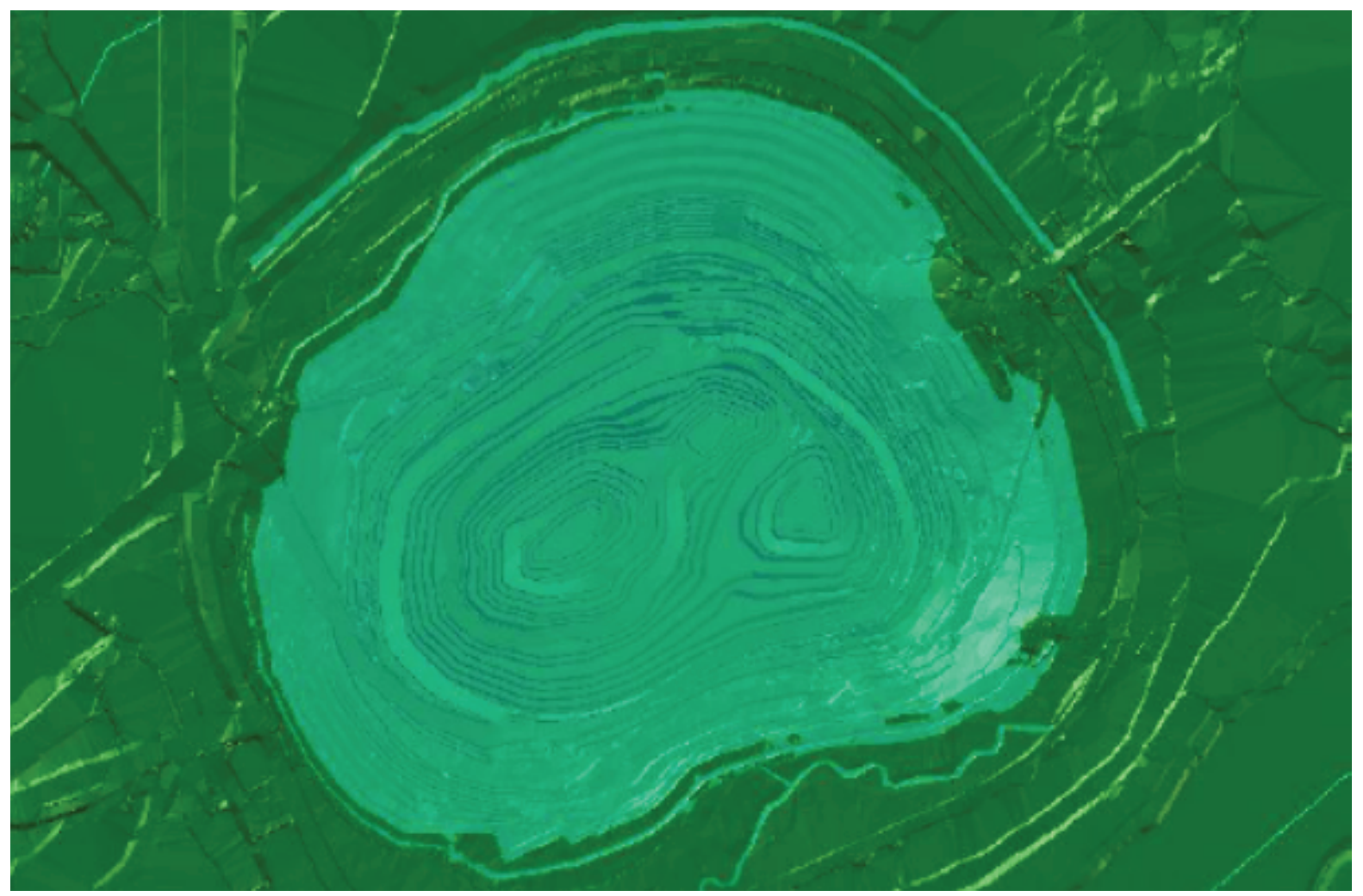

Figure 9 Plan view of Victor Pit post-closure steady-state water level (81.5 masl)

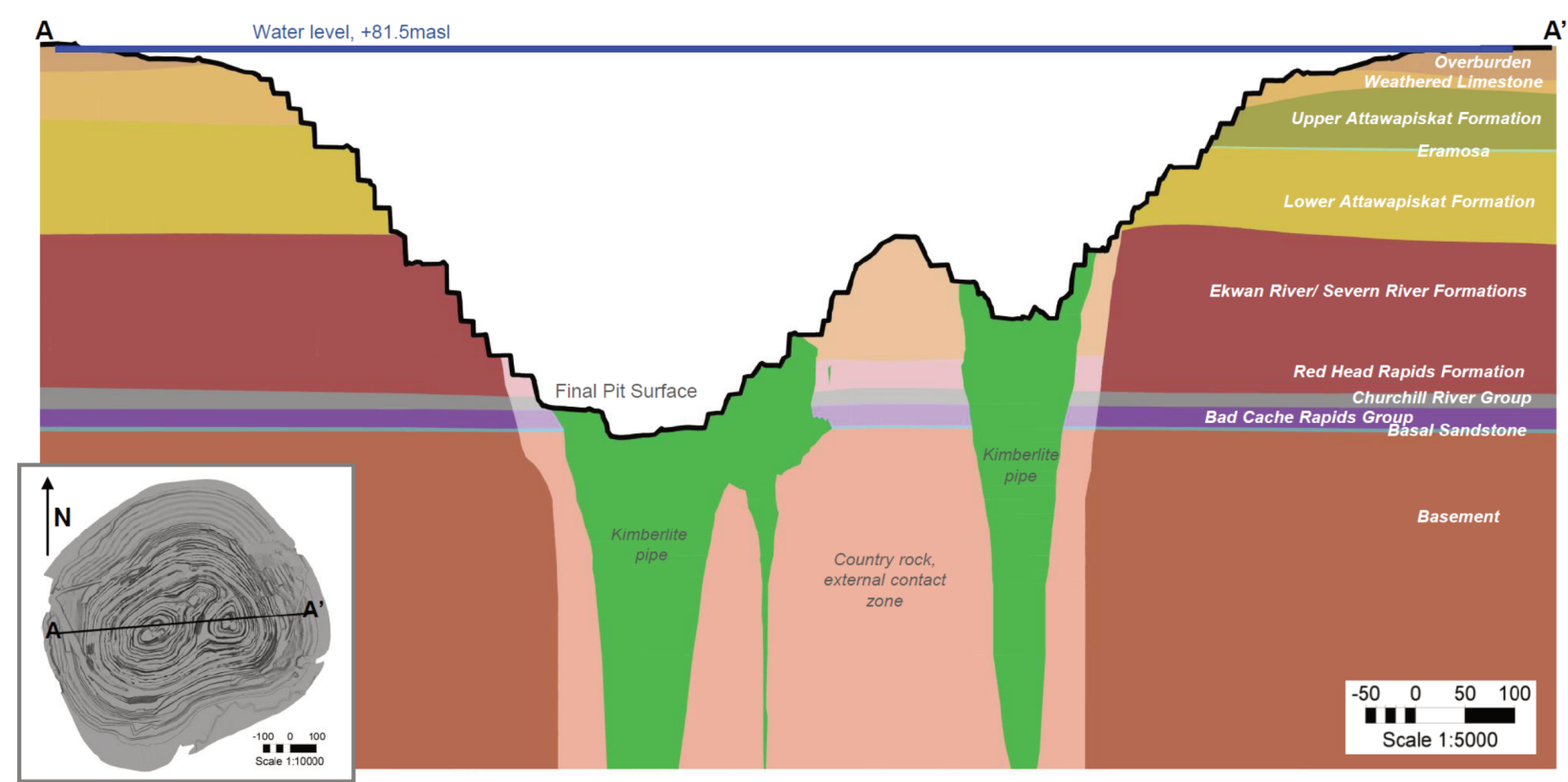

Figure 10 Victor Pit post-closure steady-state water level cross-section looking north

\subsection{Pit crest break-back analysis}

To evaluate and manage the zone of potential crest instability, the location of the ultimate long-term crest break-back must be determined. The stability analysis described in Section 3.1 do not address long-term degradation, so industry rules of thumb guidelines were compared. Local regulations pertain to geotechnical stability and monitoring of open pits during closure. These regulations state that, if a pit is flooded, a method to prevent inadvertent access must be applied outside the area susceptible to wall collapse. 
A typical method to minimise the risk of inadvertent public access to abandoned open pits involves the construction of an abandonment berm around the perimeter of the open pit. Ontario Mines Regulation (2000) state that a berm shall be set back from the toe of the pit at least a distance equivalent to the pit depth. More simply stated, this is a projection of $45^{\circ}$ from the bottom of the pit.

The WA Department of Industry and Resources (1997) have published a guideline that also states that the zone of potential instability is defined by a wedge of material extending from the toe of the pit wall at $45^{\circ}$ with an additional $10 \mathrm{~m}$ offset to the safety bund. This guideline also takes into consideration weathered rock conditions where the design angle should be further reduced to $25^{\circ}$ (Figure 11 ).

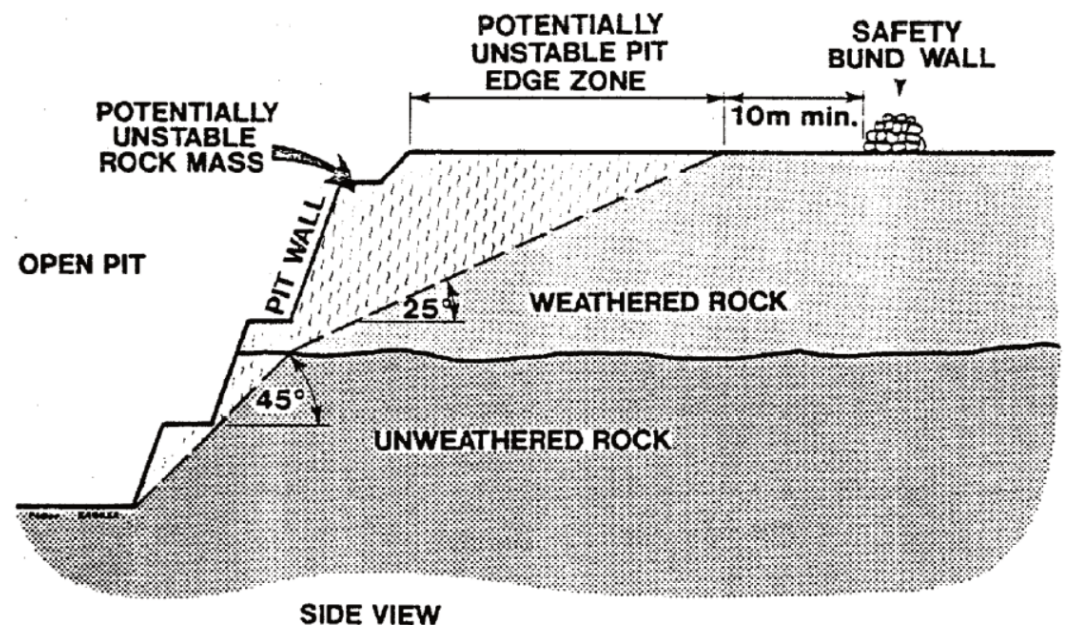

Figure 11 Western Australian guideline to determine the location of perimeter berm for closure (WA Department of Industry and Resources 1997)

As a conservative measure, the Australian guideline using the $25^{\circ}$ design angle in weathered rock was projected from both the pit toe and ramp toes. Figure 12 shows that all projections fall well within the pit ring road. This, combined with the fact that stability checks indicate FoS at ring road is well in excess of 1.6, meant that the existing pit ring road would be a convenient location for a $2 \mathrm{~m}$ high perimeter safety berm constructed with road material.

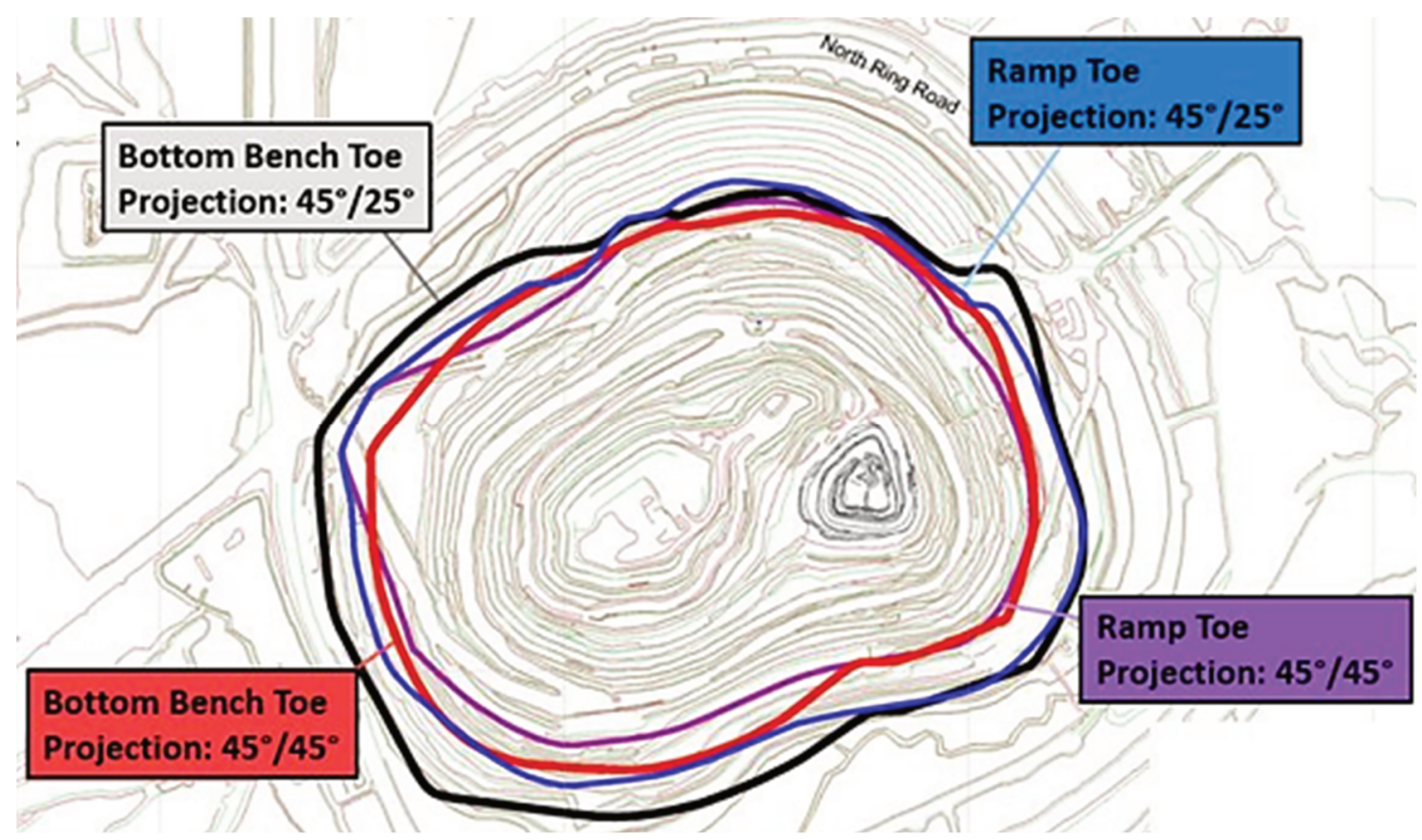

Figure 12 Projection lines to assist in determining the location of perimeter safety berm 


\subsection{Pit lake development - spreadsheet model}

A time-based pit analytical model was used to determine the rate of pit filling and the time required to reach steady state water level. The model used a simple time-step to calculate the water level at the end of each month by making sure the equation below is met on a monthly basis:

$$
\Delta V=Q_{\text {natural }}+Q_{\text {river }}+Q_{\text {precipitation }}-Q_{\text {evaporation }}
$$

The monthly refill volume by groundwater $\left(Q_{\text {natural }}\right)$ is based on the head available, which is calculated from the average water level. The evaporation volume $\left(Q_{\text {precipitation}}\right)$ is calculated by the monthly rate multiplying the average monthly surface area. The evaporation volume ( $\left.Q_{\text {evaporation}}\right)$ is calculated by the monthly rate multiplying the pit surface area. The spreadsheet model ultimately provided greater value than the use of a numerical groundwater model because of the ability to rapidly investigate different closure options, and the underlying assumptions can be clearly understood. The spreadsheet model has also proven to be more accurate than the numerical model previously developed to provide regulatory support.

Due to the low storativity of the lower geologic units, the pit was predicted to initially fill very quickly once dewatering wells were removed. Because the water level would initially rise quickly, the in-pit dewatering wells were decommissioned sequentially from the inside out. Perimeter wells continued to run to ensure work areas were not prematurely flooded. Even with permitter wells running, the water level rose at a rate of $2.5 \mathrm{~m}$ per day. The spreadsheet model predicted the pit would take approximately 10 years to fill naturally.

Before mining commenced, it was postulated that mine dewatering and the associated depression of the watertable could have a negative impact on the nearby tributaries. This was alleviated by seasonal supplementation with water from the Attawapiskat River for the life-of-mine. This supplementation may continue into post-closure until the pit lake and groundwater table have fully recovered. Various scenarios involving accelerated pit filling were evaluated to compare the effect of pit lake filling on the financial, compliance, environmental, and safety risks. Various options were compared (Table 2):

Table 2 Pit lake development options

\begin{tabular}{lll}
\hline Option & Pit lake development & Ongoing supplementation of local creeks \\
\hline 1 & No rapid filling of pit & No supplementation \\
2 & No rapid filling of pit & $\begin{array}{l}\text { Supplementation maintained until recovery } \\
\text { ( 10 years) }\end{array}$ \\
3 & $\begin{array}{l}\text { Rapid filling of the pit using a portion of the } \\
\text { supplementation water supply }\end{array}$ & Supplementation reduced to minimum \\
4 & $\begin{array}{l}\text { Rapid filling of the pit using all of the } \\
\text { supplementation water supply } \\
\text { Rapid filling of the pit using new pumping } \\
\text { infrastructure }\end{array}$ & $\begin{array}{l}\text { No supplementation } \\
\text { ( 1.5 years) }\end{array}$ \\
\hline
\end{tabular}

A high level risk comparison is presented on Figure 13. Ultimately, the option to accelerate the filling of the pit with new pumping infrastructure and continue supplementation until full recovery (Option 5) was selected. This option would pump $70,000 \mathrm{~m}^{3} /$ day from the Attawapiskat River to the pit. It was clear that this pumping rate would outweigh all other variables in the model (Figure 14). This was confirmed with a sensitivity analysis to assess the effects of reducing the pumping rate and/or reducing groundwater inflows by $15 \%$ and $30 \%$ (Figure 15 ). 


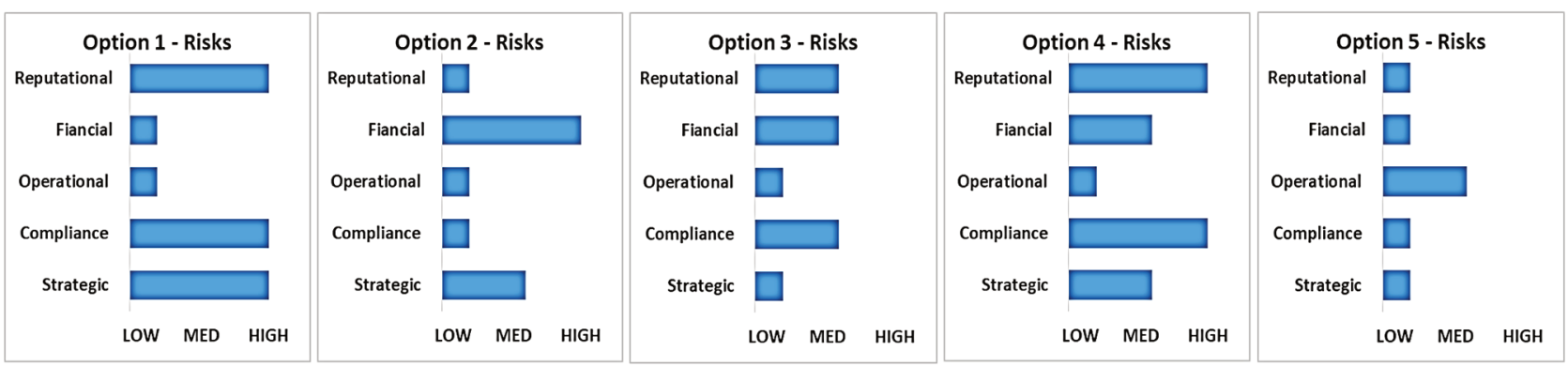

Figure 13 High level options risk comparison

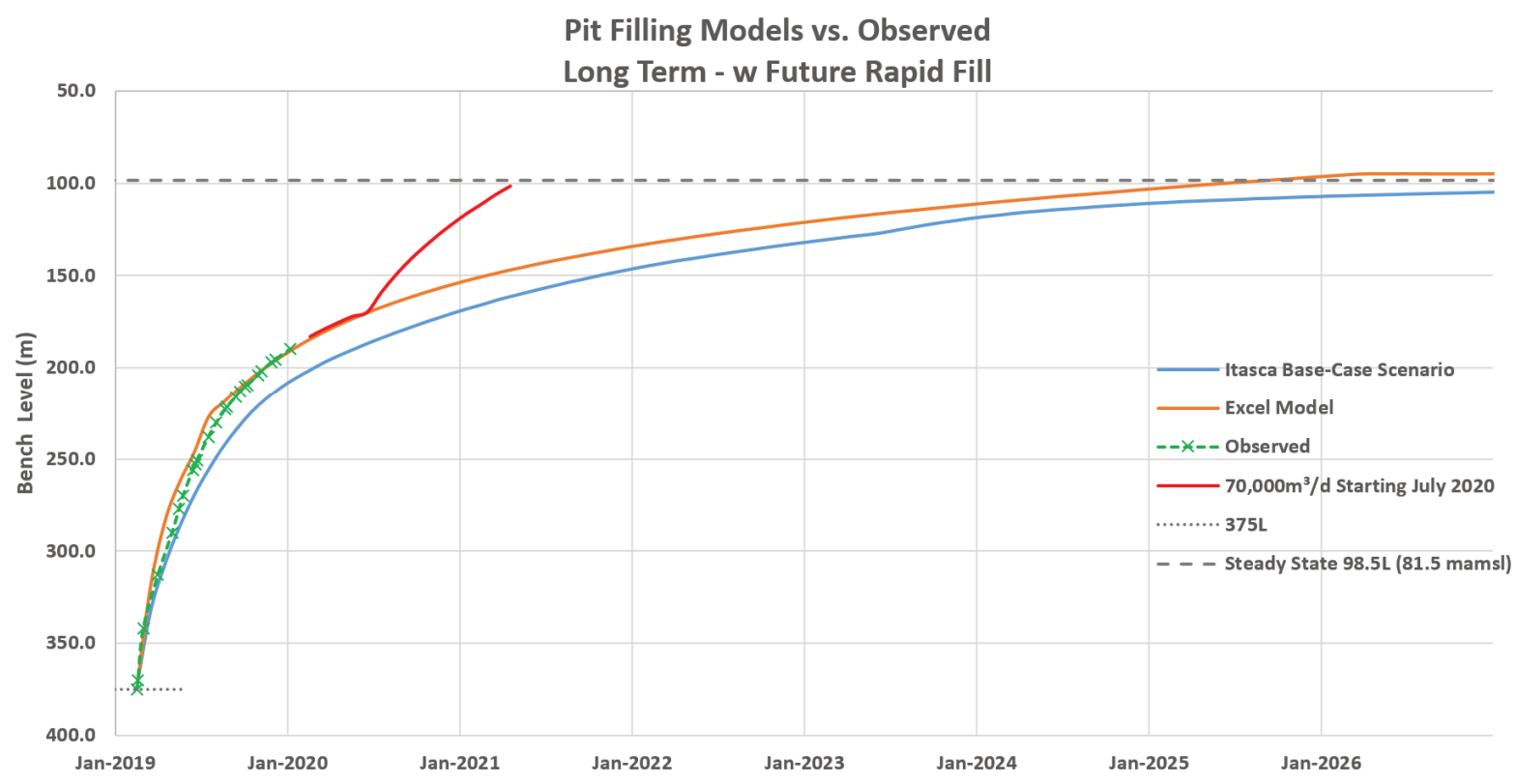

Figure 14 Pit filling model prediction versus accelerated pit filling. The predicted recovery from the spreadsheet model is shown in orange, with rapid filling shown in red. The actual observed recovery is shown in green. The recovery curve predicted by the numerical model is shown in blue

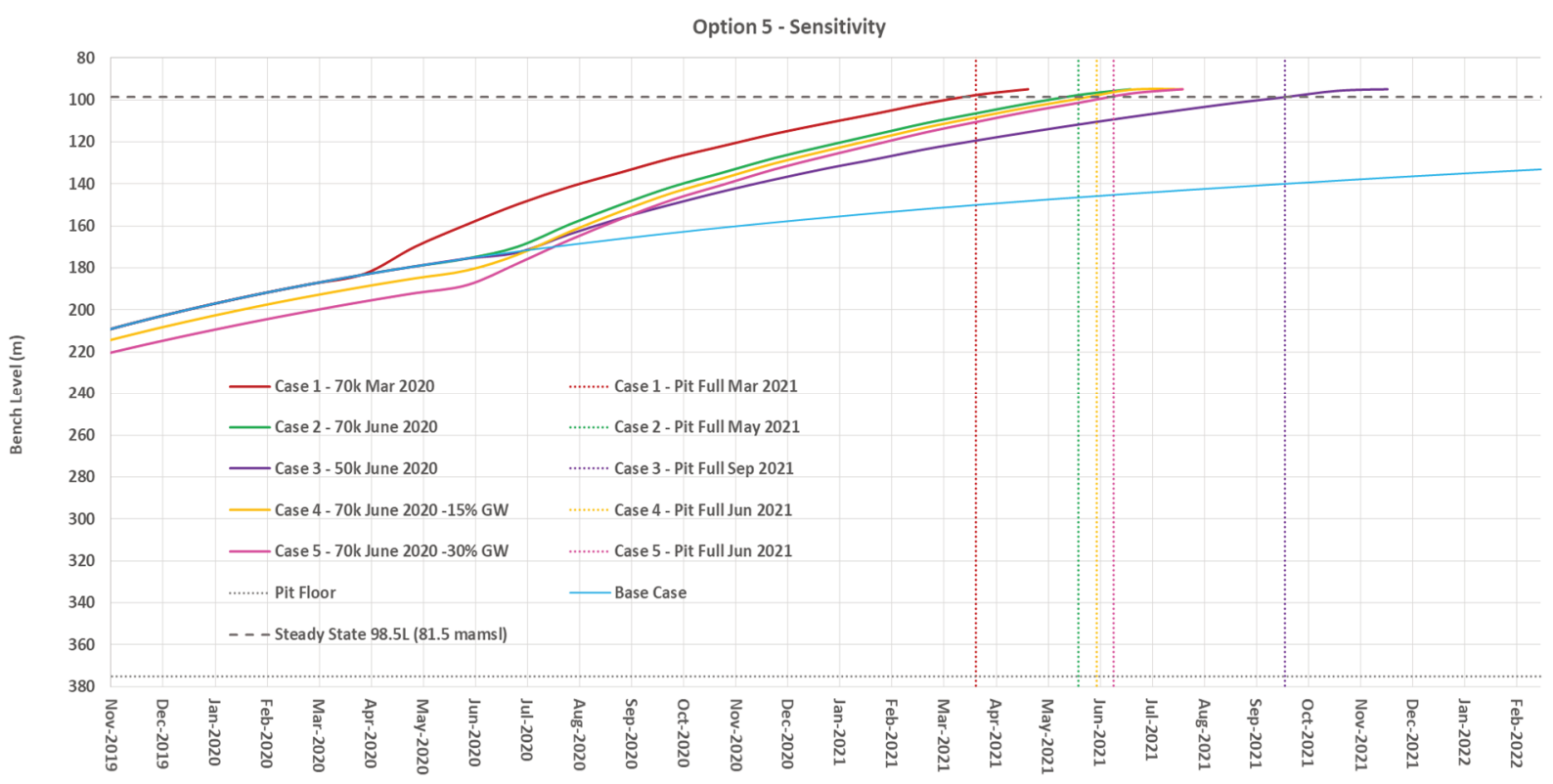

Figure 15 Option 5 sensitivity analysis 
Although there is an upfront capital cost associated with Option 5, it was selected as the preferred option for the following reasons:

- It was the fastest way to achieve regional groundwater table recovery and to achieve stabilisation of the pit concurrently with demolition and other reclamation activities. This, in turn, would minimise the cost of maintaining a remote camp.

- The option has the overall lowest cost while maintaining regulatory compliance.

- Rapid filling produces an improved pit lake water quality as the river water has lower chloride and total dissolved solids (TDS) concentrations that the natural inflowing groundwater.

- Rapid filling provides the most favourable slope stability outcome as the pit walls have less standup time and the risk associated with the public accessing hazardous highwalls is eliminated while personnel are still present onsite.

- The shortened closure time means the least number of years spent on environmental monitoring and sampling of the lakes, rivers, and creeks etc.

- It also reduces the timeline risk caused by assumptions in the hydrologic model.

\subsection{Risk workshop}

A risk workshop was held with stakeholders to evaluate potential geotechnical risks associated with closure. Based on the results of the stability and pit filling assessments, it was decided to separate closure into two stages: active closure and post-closure. Active closure was defined as the period post-production while personnel were still accessing the pit and surrounding area for decommissioning activities. Post-closure was defined as when these decommissioning activities were complete, and monitoring was on going.

The greatest safety risk identified was associated with material falling from the walls during the active closure phase due to the higher probability of small-scale failure events. The probability of these events occurring increases each day as stand-up times are increased. Therefore, the highest probability of a rockfall event will be at the end of mining and early closure when maintenance of the pit walls has ceased. The risk associated with this is high if personnel are exposed to this hazard in active closure and even more so when the timing aligns with freshet (spring melt) as it did at Victor Mine. Consequently, active rockfall management was required through the operational and closure stages. This involved periodic scaling by rope access technicians as well as localised rockfall mesh installations.

In the post-closure phase, the probability of slope failure or rockfall is greatly reduced due to the establishment of hydrostatic equilibrium which progressively reduces the exposed rock faces to only the upper slopes. During this phase, no personnel will be exposed, so the residual geotechnical risk is low.

\section{$4 \quad$ Closure plans}

\subsection{Active closure}

During production, Victor Mine relied on four slope stability monitoring systems and methods: GeoMoS Robotic Surveying System (GeoMoS), GroundProbe Slope Stability Radar (SSR), RIEGL Laser Scanner (RIEGL), and visual inspections. These monitoring systems provided early warning signs in case of slope instability.

A phased approach to monitoring was adopted for closure (Desjardins 2018). During the initial stages of closure, the existing geotechnical monitoring program remained unchanged as personnel were working in all areas of the pit. Because of the planned flooding of the pit, work needed to be completed first at the bottom of the Victor Southwest sub-pit and progress upwards. The recommended monitoring program took this decommissioning sequence into account. Four phases were used to cover the monitoring needs from the day production ceased to when all personnel are permanently offsite. These are summarised in Table 3. 


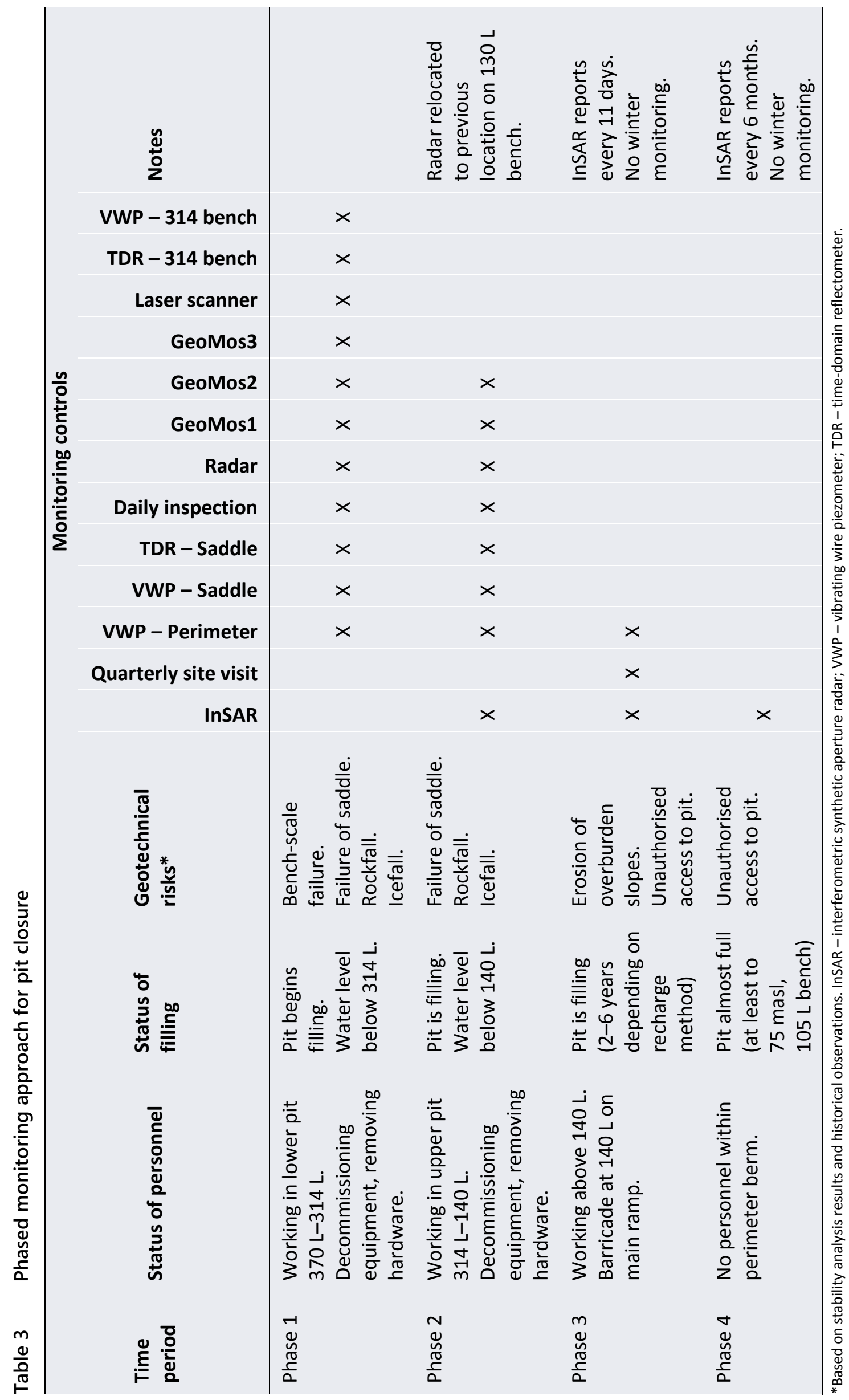


Upon initial closure, the level of geotechnical pit slope monitoring is no different than during active production mining. During this initial stage of active closure, personnel were working in the pit to decommission equipment and removing hardware and, as such, there was no change to the existing monitoring program used during production in terms of both equipment and onsite personnel. This was the highest risk phase in the life-of-mine due to the elevated porewater pressures, confined work areas, and proximity of operators to areas prone to failure (Red Head Rapids Formation and Kimberlite contact zones). The monitoring requirements decreased as the work was completed and the water level rose. To assist with visualisation of the geotechnical hazards and monitoring systems in place during different phases, geotechnical hazard maps were created (Figure 16).

The first two phases of active closure were competed without incident in June 2019, at which time the slope radar was decommissioned and relocated to another site.
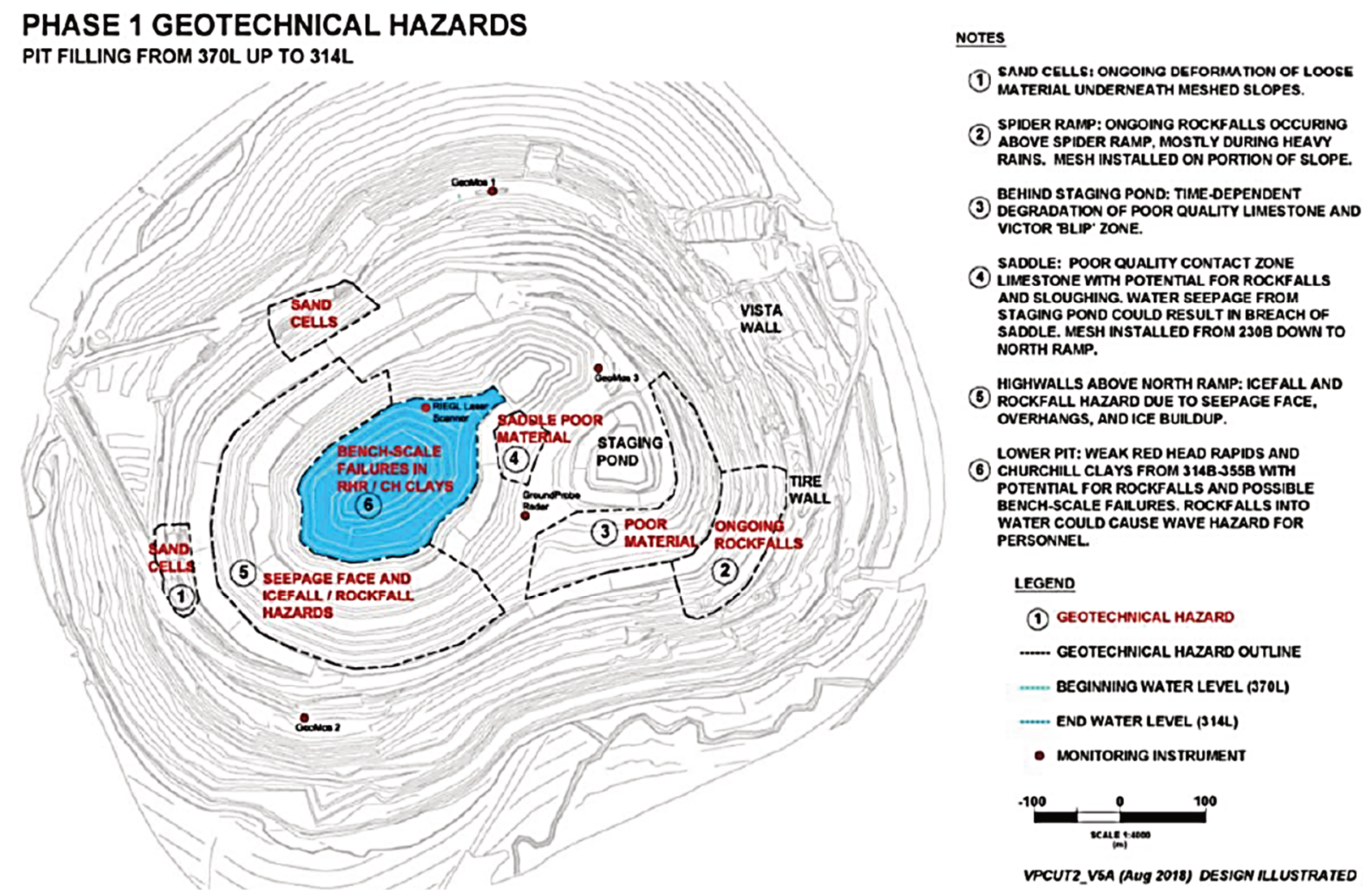

Figure 16 Example of a geotechnical hazard map created for each phase of active pit slope closure

\subsection{Post-closure}

Phase 4 monitoring applies to post-closure (i.e. the pit slope has achieved its most stable configuration and groundwater levels are largely aligned with pre-mining conditions). InSAR (interferometric synthetic aperture radar) was selected to monitor the break-back area around the pit (and other structures onsite) because of its ability to measure displacements with sub-centimetre accuracy remotely. During this phase, surface deformation monitoring relies on periodic visual inspections and InSAR reports until they are no longer deemed necessary. Once the pit lake has reached steady-state, InSAR monitoring of the pit area will be reviewed. It is expected that this will be stopped in the short to medium term as there will be no significant slopes above the water level and underwater slope failure or collapse of karstic caverns is unlikely.

A response framework or Trigger Action Response Plan (TARP) was developed for InSAR monitoring of the pit and other structures on the mine site (Figure 17). This work was reviewed and endorsed by the Victor Mine Geotechnical Review Board (de Graaf et al. 2018). 


\begin{tabular}{|c|c|c|c|c|c|}
\hline \multicolumn{6}{|c|}{ Response Framework - Victor Mine at Closure - InSAR Monitoring } \\
\hline \multirow[b]{2}{*}{$\begin{array}{l}\text { Engineering } \\
\text { Criteria }\end{array}$} & \multirow[b]{2}{*}{ Description } & \multicolumn{4}{|c|}{ Threshold Values by Category } \\
\hline & & $\begin{array}{c}\text { Green } \\
\text { (Acceptable Situation) }\end{array}$ & $\begin{array}{c}\text { Yellow } \\
\text { (Concern Situation) }\end{array}$ & $\begin{array}{c}\text { Orange } \\
\text { (Buffer Situation) }\end{array}$ & $\begin{array}{c}\text { Red } \\
\text { (Unsafe / Out of } \\
\text { Compliance) }\end{array}$ \\
\hline \multirow{4}{*}{$\begin{array}{c}\text { InSAR } \\
\text { Deformation }\end{array}$} & \begin{tabular}{|l|} 
PKC Facility: \\
Settlement, bulging at \\
toe, erosion channel or \\
sinkhole formation of \\
PKC Facility dykes or area \\
within $25 \mathrm{~m}$ of toe of dyke \\
\end{tabular} & $\begin{array}{l}\text { None to minor } \\
\text { deformation }+/-0.3 m\end{array}$ & $\begin{array}{l}\text { Deformation of } 0.3 \mathrm{~m} \text { - } \\
0.5 \mathrm{~m} \\
\text { Erosion channel depth of } \\
<0.5 \mathrm{~m} \\
\text { Sinkhole depth }<0.5 \mathrm{~m}\end{array}$ & $\begin{array}{l}\text { Deformation of } 0.5 \mathrm{~m}- \\
1.0 \mathrm{~m} \\
\text { Erosion channel depth of } \\
>0.5 \mathrm{~m} \\
\text { Sinkhole depth }>0.5 \mathrm{~m}\end{array}$ & $\begin{array}{l}\text { - Deformation }>1.0 \mathrm{~m} \\
\text { - Erosion channel depth of }> \\
1.0 \mathrm{~m} \\
\text { - Sinkhole depth }>1.0 \mathrm{~m}\end{array}$ \\
\hline & \begin{tabular}{|l|} 
Stockplies / Rock Dumps: \\
Settlement, bulging at \\
toe, erosion channel or \\
sinkhole formation on \\
stockpiles or area within \\
$25 \mathrm{~m}$ of crest and toe \\
\end{tabular} & $\begin{array}{l}\text { None to minor } \\
\text { deformation }+/-0.3 m\end{array}$ & $\begin{array}{l}\text { Detormation of } 0.3 \mathrm{~m} \text { - } \\
0.5 \mathrm{~m} \\
\text { Erosion channel depth of } \\
<0.5 \mathrm{~m} \\
\text { - Sinkhole depth }<0.5 \mathrm{~m}\end{array}$ & $\begin{array}{l}\text { Detormation of } 0.5 \mathrm{~m}- \\
1.0 \mathrm{~m} \\
\text { Erosion channel depth of } \\
>0.5 \mathrm{~m} \\
\text { - Sinkhole depth }>0.5 \mathrm{~m}\end{array}$ & $\begin{array}{l}\text { Deformation }>1.0 \mathrm{~m} \\
\text { - Erosion channel depth of }> \\
1.0 \mathrm{~m} \\
\text { - Sinkhole depth }>1.0 \mathrm{~m}\end{array}$ \\
\hline & $\begin{array}{l}\text { Victor Pit: } \\
\text { Settlement or sinkhole } \\
\text { development within } 25 \mathrm{~m} \\
\text { of Pit Exclusion Berm } \\
\text { (either side) }\end{array}$ & $\begin{array}{l}\text { None to minor } \\
\text { deformation }+/-0.3 m\end{array}$ & $\begin{array}{l}\text { Deformation of } 0.3 \mathrm{~m} \text { - } \\
0.5 \mathrm{~m} \\
\text { Erosion channel depth of } \\
<0.5 \mathrm{~m} \\
\text { - Sinkhole depth }<0.5 \mathrm{~m}\end{array}$ & $\begin{array}{l}\text { Deformation of } 0.5 \mathrm{~m}- \\
1.0 \mathrm{~m} \\
\text { Erosion channel depth of } \\
>0.5 \mathrm{~m} \\
\text { Sinkhole depth }>0.5 \mathrm{~m}\end{array}$ & $\begin{array}{l}\text { - Deformation }>1.0 \mathrm{~m} \\
\text { - Erosion channel depth of }> \\
1.0 \mathrm{~m} \\
\text { - Sinkhole depth }>1.0 \mathrm{~m}\end{array}$ \\
\hline & $\begin{array}{l}\text { Infrastructure Areas: } \\
\text { Roads, laydowns, airport, } \\
\text { building pads, fuel } \\
\text { storage, etc with } \\
\text { additional } 20 \mathrm{~m} \text { buffer } \\
\text { outside of area } \\
\end{array}$ & $\begin{array}{l}\text { None to minor } \\
\text { deformation }+/-0.3 m\end{array}$ & $\begin{array}{l}\text { Deformation of } 0.3 \mathrm{~m} \text { - } \\
0.5 \mathrm{~m} \\
\text { Erosion channel depth of } \\
<0.5 \mathrm{~m} \\
\text { - Sinkhole depth }<0.5 \mathrm{~m} \\
\end{array}$ & $\begin{array}{l}\text { Deformation of } 0.5 \mathrm{~m}- \\
1.0 \mathrm{~m} \\
\text { Erosion channel depth of } \\
>0.5 \mathrm{~m} \\
\text { - Sinkhole depth }>0.5 \mathrm{~m}\end{array}$ & $\begin{array}{l}\text { Deformation }>1.0 \mathrm{~m} \\
\text { - Erosion channel depth of }> \\
1.0 \mathrm{~m} \\
\text { - Sinkhole depth }>1.0 \mathrm{~m}\end{array}$ \\
\hline \multicolumn{2}{|c|}{ Action Required - Engineering Criteria } & $\begin{array}{l}\text { Continue monitoring } \\
\text { according to Closure } \\
\text { Monitoring Plan }\end{array}$ & $\begin{array}{l}\text { Document location and } \\
\text { details, identify potential } \\
\text { cause(s) } \\
\text { Undertake field } \\
\text { inspection to investigate } \\
\text { and validate occurrence. } \\
\text { Photograph area of } \\
\text { concern. } \\
\text { Re-asses after } \\
\text { subsequent InSAR flash } \\
\text { report } \\
\text { Plan and evaluate } \\
\text { potential mitigation } \\
\text { measures }\end{array}$ & $\begin{array}{l}\text { Document location and } \\
\text { details, identify potential } \\
\text { cause(s) } \\
\text { Suspend any activities in } \\
\text { area of concern (Active } \\
\text { Closure) } \\
\text { Undertake field } \\
\text { inspection to investigate } \\
\text { and validate occurrence. } \\
\text { Photograph area of } \\
\text { concern } \\
\text { Engineer of Record to } \\
\text { conduct site visit to } \\
\text { assess situation (involve } \\
\text { De Beers Technical } \\
\text { personnel) } \\
\text { Implement mitigation } \\
\text { measures if required } \\
\text { Reassess thresholds and } \\
\text { conditions for Red } \\
\text { Category, taking into } \\
\text { account the changing } \\
\text { conditions presently } \\
\text { observed } \\
\text { Consider terrestrial } \\
\text { survey measurements to } \\
\text { verify deformation. } \\
\text { Request detailed InSAR } \\
\text { Analysis Report } \\
\text { Consider increasing } \\
\text { InSAR reporting } \\
\text { frequency if possible } \\
\text { (maximum is one report } \\
\text { per } 11 \text { days) }\end{array}$ & $\begin{array}{l}\text { Temporary evacuation of } \\
\text { any personnel and } \\
\text { equipment from area of } \\
\text { concern (Active Closure) } \\
\text { - InSAR Report to be } \\
\text { immediately provided to } \\
\text { the De Beers Closure } \\
\text { Manager and a } \\
\text { Geotechnical Engineer } \\
\text { - Update planning and take } \\
\text { appropriate mitigation } \\
\\
\text { Undertake terrestrial } \\
\text { survey measurements to } \\
\text { verify deformation } \\
\text { Request detailed InSAR } \\
\text { Analysis Report and } \\
\text { consider 3D vector } \\
\text { evaluation }\end{array}$ \\
\hline \multicolumn{2}{|c|}{ Personnel Notified } & $\begin{array}{l}\text { - Geotechnical Engineer } \\
\text { - Asset Manager }\end{array}$ & $\begin{array}{l}\text { - Geotechnical Engineer } \\
\text { - Asset Manager } \\
\text { - De Beers Closure } \\
\text { Manager } \\
\text { - Engineer of Record }\end{array}$ & $\begin{array}{l}\text { Geotechnical Engineer } \\
\text { - Asset Manager } \\
\text { De Beers Closure } \\
\text { Manager } \\
\text { - Engineer of Record } \\
\text { Corporate Support } \\
\text { Calgary } \\
\text { Appropriate Regulatory } \\
\text { Authorities }\end{array}$ & $\begin{array}{l}\text { - Geotechnical Engineer } \\
\text { - Asset Manager } \\
\text { - De Beers Closure Manager } \\
\text { - Engineer of Record } \\
\text { - Corporate Support Calgary } \\
\text { - Appropriate Regulatory } \\
\text { Authorities } \\
\text { - Emergency Personnel } \\
\text { - Chief Executive Officer }\end{array}$ \\
\hline
\end{tabular}

Figure 17 Example of response framework for InSAR (Trigger Action Response Plan) 


\section{Conclusion}

This paper presented a case study outlining the process used to ensure that decommissioning and closure of the Victor Mine pit can occur safely, rapidly, and within regulatory guidelines. The pit can be closed quickly due to excellent historical slope performance and the opportunity to rapidly fill the pit lake with water from the nearby Attawapiskat River. The pit is expected to be filled within a two year time period, with supplementation to the local creeks ending soon after. Long-term monitoring requirements will be reviewed once the data show that the pit lake and the surrounding topographic area are stable.

\section{Acknowledgement and disclaimer}

The contributions of colleagues and consultants in developing the respective geotechnical closure management systems are acknowledged. Furthermore, permission from De Beers and Anglo American management, to publish this work is also gratefully acknowledged.

All opinions and conclusions drawn in this paper are those of the authors alone and it should not be assumed that any views expressed herein are also necessarily those of De Beers or Anglo American.

\section{References}

de Graaf, P, Johnson, R \& Beale, G 2018, Victor Mine - 2018 Geotechnical Review Board Report, unpublished report, April 2018.

de Graaf, PJH, Desjardins, M \& Tsheko, P 2019, 'Geotechnical risk management for open pit mine closure: a sub-arctic and semi-arid case study', Proceedings of the International Symposium on Mine Closure, Australian Centre for Geomechanics, Perth.

Desjardins, M 2018, Victor Mine De Beers Canada Inc. Geotechnical Closure Report, unpublished internal report, 30 September 2018. Itasca 2019, Closure of the Victor Diamond Mine: Infilling, Hydrodynamics, and Water Chemistry of the Pit Lake, Technical report prepared by Itasca Denver Inc. for De Beers Canada Victor Mine, May 2019.

Ontario Mines Regulation 2000, Mine Development and Closure under Part VII of the Act (Regulation 240/00).

Read, J \& Stacey, P 2009, Guidelines for Open Pit Slope Design, CSIRO Publishing, Collingwood.

Rougier, M, Ruest, M, Gauthier, P \& Horwitz, A 2015, 'The use of head drilling and of structural data from digital photography obtained by drone survey to justify slope steepening at Victor Diamond Mine', Proceedings of the International Symposium on Slope Stability in Open Pit Mining and Civil Engineering (Slope Stability 2015), The Southern African Institute of Mining and Metallurgy, Cape Town, pp. 485-504.

Rougier, M \& Smith, J 2017, Results of the Updated Stability Analyses and Geotechnical Review of Victor Mine Ultimate Pit Slope Designs in Rock, Technical memorandum prepared for De Beers Canada Victor Mine, January 2017.

WA Department of Industry and Resources 1997, Safety Bund Walls Around Abandoned Open Pit Mines Guideline, Government of Western Australia. 